\title{
Field-scale Calibration of Crop-Yield Parameters in the Soil and Water Assessment Tool
}

(SWAT)

\section{Sumathy Sinnathamby ${ }^{a}$, Kyle R. Douglas-Mankin', Collin Craige}

${ }^{\mathrm{a} B i o l o g i c a l}$ and Agricultural Engineering, Kansas State University, 147 Seaton Hall, Manhattan, Kansas 66506-2906. sumathys@ksu.edu

${ }^{\mathrm{b}}$ Biological and Agricultural Engineering, Kansas State University, 147 Seaton Hall, Manhattan, Kansas 66506-2906. krdmankin@gmail.com

${ }^{\mathrm{c} B i o s y s t e m s}$ and Agricultural Engineering, Oklahoma State University, 111 Agricultural Hall, Stillwater, Oklahoma 74078-6016. ccraig@ostatemail.okstate.edu

ABSTRACT. Accurate modeling of crop growth within watershed hydrological models is essential, yet most studies pay little attention to parameterizing crop-growth sub-models or validating their performance. This study evaluated crop sub-model parameters of Soil and Water Assessment Tool (SWAT), a widely used, physically based, hydrological model. Baseline SWAT crop parameters were calibrated at the model hydrologic-response-unit-scale using 10 years of replicated field-scale data at one site and validated using 5 years at a second site for corn and grain sorghum, and new parameters were developed and tested for sweet sorghum (bioenergy crop) using 4 years of unreplicated field data. Calibration of crop yields focused on four parameters: lower harvest index (WYSF), harvest index for optimal growing condition (HVSTI), radiation use efficiency (BIO_E), and maximum leaf area index (BLAI). Calibration improved model performance and resulted in slight changes to SWAT default values for four parameters for corn and sorghum. These results provide important preliminary parameters for modeling sweet sorghum in SWAT; both BIO_E and BLAI were greater than default values for grain sorghum. Calibrated parameters improved model performance in validation of corn but not grain sorghum, which was heavily influenced by drought conditions and possibly other management differences at the validation site. Results of this study support use of sitespecific, rather than default or off-site, calibration of crop-model parameters to minimize effects on model performance of different soil, water, and nutrient management conditions. Watershed-specific, field-scale crop-yield calibration methods demonstrated in this study are recommended to reduce the 
plant-growth-related systematic error component of larger-scale hydrological processes (such as streamflow).

Keywords. Hydrologic modeling, Crop model, Corn, Grain sorghum, Sweet sorghum, SWAT.

\section{INTRODUCTION}

Crop-growth models use mathematical equations to represent plant growth and development. Elements of crop-growth models that have been used over the past 30 years to address crop growth, development and yields are being incorporated into hydrological models (Sinclair and Seligman, 1996). Hydrological models often integrate crop-growth sub-models to provide accurate representation of above-ground and below-ground biomass characteristics that are important to simulating evapotranspiration (ET), soil-water and nutrient uptake, biomass pools of carbon and nutrients, and other surface and sub-surface characteristics relevant to hydrological or water-quality processes. Accuracy in crop models can be achieved through accurate inputs and better calibration of crop biomass and grain yield (Nair et al., 2011; Arnold et al., 2012).

Better modeling of crop growth and development characteristics improves simulation of hydrological, soil erosion, and nutrient transport processes. For example, Anand et al. (2007) demonstrated that calibration of runoff curve number $(\mathrm{CN})$ at the field scale in both SWAT (Soil and Water Assessment Tool; Arnold et al., 2012) and ADAPT (Agricultural Drainage and Pesticide Transport; Gowda et al., 2012: an extension of GLEAMS, Knisel and Douglas-Mankin, 2012) was closely related to plant ET through its influence on soil water. Calibration of crop biomass and yield also enable better quantification of crop residue after harvesting (Baumgart, 2005). Daggupati et al. (2015), in their article discussing recommended hydrological model calibration strategies, clearly state that errors in runoff prediction could be caused by lack of crop growth sub-model calibration. Even though calibration of the crop simulation components of watershed models demands intensive input and output comparison data and additional modeling effort, the result is better simulation of the crop elements and interactions critical to describing the hydrological system.

Calibration of crop growth or yield, however, has rarely been reported in SWAT studies (Baumgart, 2005; Gassman et al., 2007). For example, a study of SWAT hydrologic budget and crop yield simulations in the Upper Mississippi River Basin was performed without calibration (Srinivasan et al., 2010). They concluded that, with accurate spatial input, an uncalibrated SWAT model can 
satisfactorily predict the hydrologic budget and crop yields (i.e., county-level crop yield data aggregated to the four-digit hydrologic unit code (HUC) watershed scale) for large spatial areas.

Several studies have reported SWAT crop sub-model calibration. Nair et al. (2011) reported a fourstage SWAT calibration procedure, with one stage as crop yield calibration. Like Srinivasan et al. (2010), Nair et al. (2011) used county-level yield data weighted by watershed area to determine watershed-scale crop yield. Hu et al. (2007) also calibrated the SWAT 2000 crop model using countylevel yield data to better assess nitrate movement in an eastern Illinois watershed and reported corn and soybean yields with relative error from $-10 \%$ to $6 \%$. Ng et al. (2010) developed and calibrated SWAT 2005 model crop parameters for the perennial grass miscanthus (Miscanthus $\mathrm{x}$ giganteus) using 14 years of optimal above-ground and below-ground biomass and leaf area index (LAI) data simulated using a second crop growth model, BioCro.

Gassman et al. (2007) reviewed over 250 peer-review published articles on SWAT applications. In their summary of additional research needs, they highlighted the need for (a) expansion of the plant parameter database, and (b) more extensive testing (and revision) of crop growth sub-model and parameters. SWAT simulates crop yields at the hydrologic response unit (HRU) scale, which represents specific field-scale characteristics of soil, topography, and land use/management. Direct calibration of the SWAT crop sub-model is best performed at the HRU (field) scale. Currently no studies in the literature present detailed field-scale calibration and assessment of user-input SWAT model crop parameters. Thus, one of the two primary objectives of this study was to calibrate and validate SWAT 2005 corn and grain sorghum crop paramters under a range of ecoclimatic regions.

Additionally, there are little or no literature on sweet sorghum (Sorghum bicolor (L.) Moench) modeling (Perkins et al., 2011), and no SWAT database parameters currently exist for this crop (Engel et al., 2010). Creation of plant growth parameters for sweet sorghum would allow simulation of sweet sorghum's potential as a bioenergy crop (Engel et al., 2010) and the environmental impacts of its expanding useage. Therefore, the second objective of our study was to develop a new SWAT parameter dataset for sweet sorghum.

An overarching goal and contribution of this study was to demonstrate a method that watershed modeling studies can use to perform, document, and present calibration and validation of a watershedscale hydological model on the basis of field-scale crop-yield data. Here, measured plot-scale cropyield data were used to calibrate and validate crop-growth sub-model yields at the HRU scale. 


\section{MATERIALS AND METHODS}

\subsection{MODEL DESCRIPTION}

The Soil and Water Assessment Tool (SWAT) ver. 2005 is a physically based, watershed scale, continuous simulation model developed by the USDA Agricultural Research Service (ARS) (Arnold et al., 1998; Neitsch et al., 2004, 2005) and extensively used throughout the world (Gassman et al., 2007; Douglas-Mankin et al., 2010a; Tuppad et al., 2011; Arnold et al., 2012). It is capable of simulating crop growth, soil water, surface water, and groundwater movement as well as sediment and nutrient transport for both large and small scales (Luo et al., 2008). The model is often used to examine the effects of agricultural practices on water quality because of its ability to represent numerous management practices, including fertilizer, tillage, crop rotations, irrigation, and drainage (Arabi et al., 2008; Gassman et al., 2007; Douglas-Mankin et al., 2010a). SWAT has been used in many locations within Kansas, ranging from field scale (Anand et al., 2007; Maski et al., 2008; Douglas-Mankin et al., 2010b) to watershed scale (Parajuli et al., 2009a,b,c; Tuppad et al., 2010a,b; Daggupati et al., 2011; Nejadhashemi et al., 2011; Sheshukov et al., 2011a,b,c; Lee and DouglasMankin et al., 2011; Gali et al., 2012; Douglas-Mankin et al., 2013), and in many other study regions (Gassman et al., 2007; Douglas-Mankin et al., 2010a; Tuppad et al., 2011). The incorporation of a large number of agricultural practices and structures, enhances its ability to model crop yields (Douglas-Mankin et al., 2010a).

Plant growth in SWAT is simulated using a simplified version of the generic crop growth model from EPIC (Williams et al., 1984; Williams, 1995), as described in Neitsch et al. (2005). Total plant biomass is incremented daily based on an atmospheric- $\mathrm{CO}_{2}$-dependent radiation use efficiency applied to intercepted photosynthetically active radiation. This potential biomass accumulation is attenuated by the maximum among several possible limiting plant stresses (water, temperature, N, or P) (Luo et al., 2008). Leaf area index (LAI), green leaf area per unit land area, is also incremented daily on the basis of accumulated potential heat units (PHUs), and is also attenuated by a plant-stress factor. LAI increases until a crop-specific maximum LAI is achieved, then remains constant until onset of senscence, after which it declines linearly to zero at harvest. Similarly, canopy height increases until a crop-specific maximum is reached, but it remains at this height through the remainder of the growing season. Root biomass is incremented daily as a fraction of total plant biomass ranging from 0.4 at emergence to 0.2 at maturity according to accumulated PHUs (users may 
also input root fractions in crop.dat). Root depth for annual crops is incremented daily accoring to accumulated PHUs until maximum root depth for that crop is achieved. Harvested crop yield is simulated as a fraction, defined by a harvest index, of either total or above-ground biomass at the time of harvest, to account for harvested grain (only) or plant biomass, depending on the crop.

\subsection{STUdy Areas}

This study used field-level crop yield and management data from two research field sites (Figure 1) to calibrate and validate the SWAT model and crop sub-model parameters.

Site RK. Site RK (Riley County, Kansas) used crop grain yield data for corn (Zea mays) and grain sorghum (Sorghum bicolor) from 1999 to 2008 and sweet sorghum (Sorghum bicolor (L.) Moench) from 2007 to 2010 (KSU-AES-CES, 1999-2008a,b; Propheter, 2009; Dr. Scott Staggenborg, 2011, personal communication) from Northeastern Kansas field plots with silt loam soils for calibration. The three fields vary from 1.7 to 3.1 ha (4.1 to $7.8 \mathrm{ac}$ ). Corn was alternated annually with soybeans on fields with 3.0\% average slope and soil KS-1614050-1 (Ivan and Kennebec silt loams, hydrologic soil group B) on odd years and, during even years, on 1.3\% average slope and soil KS-1617170-1

(Reading silt loam, hydrologic soil group B). Grain sorghum was grown on the same fields with corn, so the same soil types were used. A similar rotation method was implemented, alternating with soybeans every year, with grain sorghum on KS-1614050-1 in odd years and KS-1617170-1 in even

years. Sweet sorghum was grown also using a rotation with soybeans on areas with the same soil type as corn and grain sorghum. Management practices were obtained for each crop, including fertilization, planting, harvest (table 1), and tillage dates and practices. Field cultivator tillage was applied for corn 3 months before planting, 22 days after planting, and 1 month prior to next year soybean rotation. For grain and sweet sorghum, generic no-till mixing characteristics (25 mm mixing depth, $5 \%$ mixing efficiency) were applied in SWAT. Herbicides were used on crops but were not included in management practices, because pest or pesticide impacts were not modeled. No irrigation was used during the study period. Time-based management operations were used instead of the default method, which used the fraction of PHU.

The research fields were within the 4,800-ha Cedar Creek-Big Blue Watershed (HUC 102702050705), Riley County, Kansas (Figure 1). Land-use distribution in this watershed was $32 \%$ hay/pasture, $23 \%$ residential area, 16\% deciduous forest, 11\% soybeans and 8\% corn (USGS, 1992). Soil was predominantly hydrologic group C followed by group B (USDA, 2011). The watershed was 
delineated into 31 subwatersheds with SWAT 2005 using a 10-m resolution digital elevation model (DEM) from National Elevation Dataset (USGS, 2010). Land-use data were derived from the 2010 National Agricultural Statistics Service (NASS) Cropland Data Layer at 30-m resolution (Mueller and Seffrin, 2006) and soil data derived from Soil Survey Geographic Database (SSURGO) data (USDA, 2011) processed for input to SWAT using a utility developed by Sheshukov et al. (2011b). Slope classes were calculated using the DEM. A total of 3,126 HRUs, each representing specific combinations of soil, slope, and land-use, were generated from these data. The 2 HRUs with soil, slope, and land-use characteristics corresponding to the research fields was used for this analysis.

Weather data, including precipitation, temperature, wind speed, humidity and solar radiation, were obtained from the National Climatic Data Center (NCDC, 2011) and collected at a station approximately $1.9 \mathrm{~km}$ south of the study fields for 1989 to 2008 (Figure 1b). Potential evapotranspiration (PET) was calculated using the Hargreaves method (Hargreaves and Samani, 1985). Daily curve number calculation method used plant evapotranspiration rather than available moisture capacity to adjust antecedent soil moisture condition. These changes to basin-level initial setup were based on a previous study in north-east Kansas (Sheshukov et al., 2013).

Site TO. Site TO (Texas County, Oklahoma) used crop yield data for corn and grain sorghum (OCES, 2006 - 2010) from Oklahoma State University grain sorghum and corn performance trials at the Joe Webb Farm and the Oklahoma Panhandle Research and Extension Center (OPREC) field plots to validate corn and grain sorghum calibration results from Site RK. The three fields range from 18 to 63 ha (44.5 to $155.7 \mathrm{ac}$ ). Corn and grain sorghum were each grown continuously on fields with $0.9 \%$ average slope and OK139Rc-5 soil (Richfield clay loam soil, hydrologic soil group D). The corn plots were irrigated in April (with $76.2 \mathrm{~mm})$, May (76.2 mm), June (152.4 mm), July (152.4 mm) and August $(50.8 \mathrm{~mm})$ and well fertilized, whereas the grain sorghum plots were not irrigated and had only a small amount of fertilizer applied (table 2). Management operations used in Lower Golf Creek watershed are given in table 2. Strip-tillage was carried out before every planting. These fields were within the 12,767.1-ha Lower Golf Creek Watershed (Figure 1). Watershed land cover was comprised of $51 \%$ rangeland/open area, $23 \%$ wheat, $8 \%$ general agriculture, $6 \%$ corn, $5 \%$ grain sorghum, and $5 \%$ residential areas, with the remainder comprised of miscellaneous crops (USGS, 1992). Hydrologic soil groups D and B were the dominant soil types, with a Richfield clay loam (group D) covering $46.7 \%$ of the watershed (USDA, 2011). Similar data were used as in Site RK, including 30-m DEM, NASS land-use, and SSURGO soils data. Two HRUs were selected for analysis, one each for corn 
and grain sorghum. These HRUs had substantially different characteristics (different hydrologic soil group and slope) from those selected for corn and grain sorghum calibration at Site RK.

Weather data were obtained from the Oklahoma Mesonet for 1999 to 2010 (http://www.mesonet.org) and included precipitation, maximum and minimum temperature, relative humidity, solar radiation and wind speed. The weather station was located within the watershed approximately $4 \mathrm{~km}$ southwest of the study sites. The Hargreaves method (for PET) and the plant evapotranspiration option (for curve number) were selected.

\subsection{CALIBRATION AND VALIDATION}

Four plant parameters and five soil/hydrologic parameters were adjusted for HRUs that contained the study field sites to calibrate the crop yields for corn, grain sorghum, and sweet sorghum. These were based on the authors' experience with application of SWAT and its crop submodel and consistent with sensitivity analysis of SWAT by Nair et al. (2011) and Tybula et al. (2015), and values used in calibration in other published studies (Baumgart, 2005; Hu et al., 2007; Neitsch et al., 2005; Ng et al., 2010). Trybula et al. (2015) found radiation use efficiency (BIO_E), base temperature (T_BASE), optimum temperature (T_OPT), the point in the growing season when LAI declines (DLAI), and the $\mathrm{N}$ fraction of harvested biomass (CNYLD) to be the most sensitive SWAT crop submodel parameters for simulations biomass yield, and base temperature (T_BASE) and maximum potential leaf area index (BLAI) for simulation of water yield. Nair et al. (2011) determined the most sensitive parameters for crop submodel calibration were BIO_E, harvest index for optimal growing condition (HVSTI, fraction of above-ground biomass removed during harvest), BLAI, and the fraction of $\mathrm{N}$ in plant at emergence (BN1), half maturity (BN2), and maturity (BN3). Thus, the plant parameters modified in this study included HVSTI, lower harvest index (WYSF, HVSTI under highly water stressed conditions), BIO_E, and BLAI. Other sensitive parameters (T_BASE, BN1, BN2, BN3, BP1, BP2, BP3) were modified from grain sorghum parameters a priori following Perkins et al. (2011), Propheter (2009), and BAE (2006). The remaining crop parameters were applied directly from those used for grain sorghum in SWAT.

The soil/hydrologic parameters included soil evaporation compensation factor (ESCO), plant uptake compensation factor (EPCO), soil available water capacity (SOL_AWC), biological mixing efficiency (BIOMIX), and the nitrate percolation coefficient (NPERCO). These parameters were adjusted to improve the yield results based on SWAT water stress and nutrient stress calculations. The 
ranges of values for ESCO and EPCO were chosen based on unpublished flow calibration done by the authors for Irish Creek, Black Vermillion watershed, which is located approximately $45 \mathrm{~km}$ northeast of the study watershed. Ranges for the other parameters were set based on extensive experience by the authors in calibrating SWAT for other watersheds in the study region and were fixed for both study Sites RK and TO.

Corn and grain sorghum annual grain yields were calibrated at Site RK using model results from 1999-2008 with a 2-year (1997-1998) model warm-up period. The model was calibrated for each crop individually using four plant parameters (BIO_E, HVSTI, WYSF, and BLAI) followed by soil and hydrologic parameters. Resulting annual yield simulations were compared to the observed annual grain yields from individual study plots using Nash-Sutcliffe efficiency (NSE) (Nash and Sutcliffe, 1970), percent bias (PBIAS), and RMSE-observations standard deviation ratio (RSR) (Moriasi et al., 2007, 2015). Final calibration values represent the best possible NSE and PBIAS.

Sweet sorghum yield was calibrated at Site RK using model results from 2007-2010 with a 3-year (2004-2006) model warm-up period. Growth parameters were set based upon work done by Perkins et al. (2011), Propheter (2009) and Oklahoma State University (BAE, 2006) for most parameters (table 3). As with corn and grain sorghum, four plant parameters were used for sweet sorghum yield calibration. These parameters were tested over ranges consistent with prior sweet sorghum literature (Perkins et al., 2011: BIO_E $=$ 55, HVSTI = 0.98, and WYSF = 0.98; BAE, 2006: BIO_E = 39, HVSTI $=0.90$, WYSF $=0.90$, and BLAI = 6). Both harvest indexes (WYSF, HVSTI) were tested over the upper end of index range (0.90 to 1.00) to represent hand-harvesting methods used to collect these above-ground biomass yield data (Perkins, 2012). The BIO_E value was tested from 39 to 59, and BLAI was tested from 5 to 6 . Each parameter was changed individually, and resulting biomass yield simulations were compared to the actual annual biomass yields from individual study plots, as described for corn and grain sorghum.

Corn and grain sorghum yields were validated at Site TO using model results from 2006-2010 with a 2-year (2004-2005) model warm-up period. Parameters from the Site RK calibrated model were used except where Site TO site-specific data existed (such as precipitation, temperature and management practices given in table 2). Crop growth parameters were unadjusted. 


\section{RESULTS AND DISCUSSION}

\subsection{SWeEt Sorghum Parameter DeVElopMent}

SWAT sweet sorghum predictions with newly developed parameter values (table 3) were compared with actual yields from 2007 to 2010. Sweet sorghum performed satisfactorily for 3 of the 4 years of yield data available for this study (Figure 2). SWAT predicted sweet sorghum yields to within $2 \mathrm{Mg} /$ ha for 2007, 2008 and 2010. Sweet sorghum yield in year 2009 was under predicted by $6.8 \mathrm{Mg} / \mathrm{ha}$ possibly due to over-representation of water and temperature stress (similar to the grain sorghum validation at the TO site). Statistical results for all 4 years (including the 2009 drought year) were NSE of -0.28 , PBIAS of $14.0 \%$ and RSR of 0.88 . Excluding year 2009 improved the model performance statistics to NSE of 0.97 , PBIAS of $8.95 \%$ and RSR of 0.16 . The current calibration shows promise for adequate modeling of sweet sorghum biomass yields. However, the strong influence of this single year with potential-outlier environmental conditions demonstrates both the practical concerns and statistical limitations of these results based on a limited 4-year dataset.

Other experimental studies on sweet sorghum have found wide ranges of measured BIO_E and BLAI values. Roncucci et al. (2014), for a range of irrigation treatments over 2 years of study in Pisa, Italy, found BIO_E ranging from 20 to $42 \times 10^{-1} \mathrm{~g} / \mathrm{MJ}$, which generally increased with increasing irrigation amounts. Empirical values of BIO_E from field data, subject to various environmental limitations, would be expected to be less than theoretical maximum BIO_E (for ideal growing

conditions) used for crop modeling, such as the $50 \times 10^{-1} \mathrm{~g} / \mathrm{MJ}$ found in this study (table 3 ). Roncucci et al. (2014) also found BLAI of 2.1 to 4.7, which also increased with increasing irrigation amounts. Sakellariou-Makrantonaki et al. (2007) found BLAI ranging from 7.5 to 8.0 under a range of irrigation conditions in Central Greece, compared to 2.5 for no irrigation. Hlophe (2014) found BLAI ranged from 6.0 (dryland) to 6.5 (irrigated) in Pretoria, South Africa. BLAI also varied amond five sweet sorghum cultivars from 1.5 to 4.0 (Almodares et al., 2007). Overall, these values bounded the BLAI of 6 found in this study (table 3) and also generally demonstrated lower BLAI values under more-limiting irrigation conditions (and possibly other environmental limitations), as would be expected compared to the "optimal" BLAI parameter intended for use in a crop model. 


\subsection{CORn ANd Grain SORghum CALIBration}

The calibrated SWAT model performed well in simulating corn yields at Site RK, with NSE of 0.45 , PBIAS of $0.38 \%$ and RSR of 0.74 . Corn yield simulations were reasonable for most years, but had larger deviations in 1999, 2001, 2006 and 2008 (Figure 3). Heavy rains in 1999 during June and July may have removed a portion of the applied nitrogen fertilizer (KSU-AES-CES, 1999-2008b). SWAT may have underestimated fertilizer runoff/removal, resulting in overestimated yield predictions. Bora and Bera (2004) found SWAT suitable for predicting sediment and nutrient loads on a monthly time scale, except for months with extreme storms and hydrologic conditions. This variance may have been further exacerbated with $22 \mathrm{~kg} / \mathrm{ha}$ more $\mathrm{N}$ being applied in 1999 than any other year. A hailstorm on June 16, 2001, which shredded the corn leaves resulting in diminished crop yields, likely resulted in the overestimated corn yields in 2001. It is also possible that dry weather allowed herbicide residue from the previous year's soybean rotation to remain in the field, damaging young corn plants. In addition, stalk rot in late August may have halted grain fill prematurely. Low modeled yields in 2006 may be the result of decreased rainfall in June. A measured $4.6 \mathrm{~cm}$ of rain in June compared with the normal average of $13 \mathrm{~cm}$ could have caused SWAT to overestimate water stress, while increased rain during the critical grain-fill period in August could have made it possible for full grain development.

The number of corn cultivar plots with yield data varied among years from 36 to 102 plots with yields ranging from from 1.5 to $12.3 \mathrm{Mg} / \mathrm{ha}$ (28 to $227 \mathrm{bu} / \mathrm{ac}$ ) (Figure 3). Similar figures for other

years may account for some variance among modeled and actual yields. Ideal growing conditions in 2008 may account for the high observed yields relative to modeled yield, with SWAT over estimating plant stress (KSU-AES-CES, 1999-2008b).

Simulated yields for grain sorghum visually followed actual yields very well, but a large overprediction in yield for 1999 decreased statistical values to NSE of 0.14 , PBIAS of $4.0 \%$ and RSR of 0.76 (Figure 4). It is worth noting, however, that when the 1999 outlier value is excluded from statistical calculations, the model statistics are greatly improved to NSE of 0.76 , PBIAS of $0.26 \%$ and RSR of 0.49. SWAT predicted grain sorghum yields better than corn yields, estimating close to actual yields in all years except 1999. Heavy rains in 1999 are suspected to have washed away a portion of the $\mathrm{N}$ fertilizer resulting in a growth effect similar to that of corn (Figure 3), with low observed yields 
and high predicted yields (KSU-AES-CES, 1999-2008a). Use of only crop yield data with no drought, nutrient, or temperature stress is consistent with model recommendations (Neitsch et al., 2004).

Four plant growth parameters were used to calibrate corn and grain sorghum yields (table 4). BIO_E and HVSTI were reduced from default values for corn to reduce overall simulated yields. BLAI was reduced from default values for corn to decrease simulated yield and reduce water stress. However, both HVSTI and BLAI were increased from default values for grain sorghum to increase overall simulated yields. The simulated yield during higher water-stress years was increased by increasing WSYF in both crops. BIO_E for grain sorghum was unchanged from the default value.

Other studies have calibrated corn crop model parameters in SWAT, but no studies were found that calibrated grain sorghum. Hu et al. (2007) increased BIO_E to 46 and increased BLAI to 5 as a result of calibration. Baumgart (2005) calibrated corn yield to 8 years of data and found improved performance by decreasing BIO_E to 30, increasing BLAI to 3.5, and decreaing HVSTI to 0.45. These values bounded the calibration results of this study (table 4), which found optimal performance by decreasing BIO_E to 35, increasing BLAI to 5, and decreasing HVSTI to 0.46. Because BLAI may be impacted by plant densities, and the default values correspond to plant densities associated with rainfed agriculture (Neitsch et al., 2004), variations in BLAI among studies are expected.

Fewer hydrological and soil parameters were chosen for editing, and these were only modified slightly (table 5). EPCO was decreased from the default value to allow plants to meet water needs from lower soil layers to reduce water stress, and ESCO was decreased to allow moisture from lower soil levels to be drawn into upper layers to decrease water stress. SOL_AWC, BIOMIX, and NPERCO were each adjusted to improve crop yield model performance. Raising or lowering the soil moisture can greatly affect yields, and for this reason the soil moisture was changed by no more than $7 \%$ of its original value. NPERCO determines the relation between nitrate removed in runoff and nitrate allowed to percolate through the soil layers. As NPERCO decreases, more nitrate is allowed to percolate through the soil profile, where it is more likely to be available for plant use. Lastly, BIOMIX determines the mixing of soil nutrients among soil layers by biological organisms (Neitsch et al., 2005). The contribution of biological mixing tends to increase as tillage decreases (Mankin et al., 1996), based on increasing levels of connected macropores from moldboard tillage to chisel tillage to no tillage. As such, the minimal tillage (field cultivator, only) on field plots in this study was used as rationale for increasing BIOMIX. This factor was classified as a soil parameter because of its 
influence on soil characteristics, even though it is not a soil parameter in the sense that it is dependent upon biological organisms.

The SWAT model predicted corn and grain sorghum yields moderately well after adjusting the soil and crop growth parameters. The selection of Hargreaves method (for PET) and the plant evapotranspiration option (for curve number) at the basin level before any parameter adjustments had initially improved the model performance greatly. Both corn and grain sorghum had similar parameter values after calibration. However, three of four default values for corn were decreased to decrease simulated yields while three of four default values for grain sorghum were increased to increase simulated yields (table 4). It was concluded that the greater drought-tolerance of grain sorghum made it less susceptible to plant stress, and the lesser drought-tolerance of corn made it more susceptible to plant stress than was simulated in SWAT for this region.

\subsection{CORN AND GRAIN SORGHUM VALIDATION}

To validate the corn growth parameters, the same growth calibration values found for the RK study site were used for the TO study site (Figure 5). The validation run resulted in fair statistical results with NSE of 0.25 , PBIAS of $-11.22 \%$ and RSR of 0.89 . An additional validation run was made after adjusting the BIOMIX factor, which was found to improve results if left at the default value of 0.2. This modified validation simulation resulted in good statistical results with NSE of 0.70 , PBIAS of $0.68 \%$ and RSR of 0.54. Most years were modeled well except for 2006, which was over-predicted by SWAT. This may be the result of a number of hailstorms in the Oklahoma panhandle, which reduced yields (OCES, 2006). These statistics show that the corn calibration was accurate and applicable even over a large climate range in the Midwest US.

The grain sorghum growth parameter values were validated in a similar method using yields acquired from test plots at the TO site (Figure 6). Though beyond the scope of normal model validation, model performance was also assessed by adjusting BIO_E to account for the different climate and management stress factors (Baumgart, 2005), by lowering the value from 33.5 (from RK calibration) to 24. Yields were modeled for five years, and all years except 2007 and 2009 performed well. The two years of poor performance both experienced abnormally low growing-season (MaySept.) rainfall: $14.5 \mathrm{~cm}$ in 2007 and $17.0 \mathrm{~cm}$ in 2009 compared to a long-term growing-season average of $33.1 \mathrm{~cm}$ (OCES, 2007; 2009). It appears that SWAT-simulated yield reductions overestimated the impact of the resulting crop water stress. Because of the drought years, the 
calibration statistics are less than satisfactory, with NSE of -2.6, PBIAS of $-10.7 \%$ and RSR of 1.9. Removing data for the two drought years, statistics were improved to NSE of -0.8, PBIAS of 8.6\% and RSR of 0.7. Grain sorghum simulations might have performed more poorly than corn because the corn plots were irrigated, which minimized the potential for plant water stress that was evident with grain sorghum. This under-prediction of grain sorghum crop yields by SWAT during drought years likely causes under-estimation of other crop-related processes, such as canopy cover, ET, and nutrient uptake, and may impact model performance in simulating hydrological and constituent responses in watersheds with substantial grain sorghum production.

\section{CONCLUSION}

These results provide preliminary SWAT crop-model parameters for an important bioenergy crop, sweet sorghum. Overall, SWAT was able to predict crop yields for corn, grain sorghum, and sweet sorghum reasonably accurately and over a range of climatic conditions. Calibration improved model performance statistics for corn validation simulation but not for grain sorghum, which was heavily influenced by drought conditions and possibly other management differences at the validation site. Results of this study support use of site-specific, rather than default or off-site, calibration of cropmodel parameters to minimize effects on model performance of different soil, water, and nutrient management conditions. Attention to crop-yield calibration by model practitioners may result in more-robust model calibrations at the field and watershed scales by factoring out the systematic error component associated with plant-growth calibration prior to calibrating larger-scale hydrological processes (such as streamflow).

\section{ACKNOWLEDGEMENTS}

This material is based upon work supported by National Science Foundation Grant \#1062895, "REU Site: Summer Academy in Sustainable Bioenergy", awarded to Kansas State University.

\section{REFERENCES}

Almodares, A, Taheri, R., Adeli, S., 2007. Inter-relationship between growth analysis and carbohydrate contents of sweet sorghum cultivars and lines. J. Environmental Biology 28(3): 527531. 
Anand, S., Mankin, K.R., McVay, K.A., Janssen, K.A., Barnes, P.L., Pierzynski, G.M., 2007.

Calibration and validation of ADAPT and SWAT for field-scale runoff prediction. J. Amer. Water Resour. Assoc. 43(4): 899-910.

Arabi, M., Frankenberger, J. R., Engel, B.A., Arnold, J.G., 2008. Representation of agricultural conservation practices with SWAT. Hydrol. Process. 22: 3042-3055.

Arnold, J.G., Srinivasan, R., Muttiah, R.S., Williams, J.R., 1998. Large area hydrologic modeling and assessment. Part I: Model development. J. Amer. Water Resour. Assoc. 34(1): 73-89.

Arnold, J.G., Moriasi, D.N., Gassman, P.W., Abbaspour, K.C., White, M.J., Srinivasan, R., Santhi, C., Harmel, R.D., van Griensven, A., Van Liew, M.W., Kannan, N., Jha, M.K., 2012. SWAT: Model use, calibration, and validation. Trans. ASABE 55(4): 1491-1508.

Biosystems and Agricultural Engineering Department (BAE), 2006. Predicted sweet sorghum yields in Oklahoma by soil and climate region. Stillwater, Oklahoma, Oklahoma State University. Available at: http://www.ars.usda.gov/SP2UserFiles/ad_hoc/62060505MikeWhite/pdfs/Sorghum725-2006.pdf. Accessed 30 August 2012.

Baumgart, P., 2005. Lower Green Bay and Lower Fox Tributary Modeling Report. Science and Technical Advisory Committee of the Green Bay Remedial Action Plan. 46-50. Available at: http://www.uwgb.edu/watershed/reports/related_reports/load-allocation/lowerfox_tss-p_loadallocation.pdf , Accessed January 11, 2012.

Daggupati, P., Douglas-Mankin, K.R., Sheshukov, A.Y., Barnes, P.L., Devlin, D.L., 2011. Field-level targeting using SWAT: Mapping output from HRUs to fields and assessing limitations of GIS input data. Trans. ASABE54(2): 501-514.

Daggupati, P., Pai, N., Ale, S., Douglas-Mankin, K.R., Zeckoski, R.W., Jeong, J., Parajuli, P.B., Saraswat, D., Youssef, M.A., 2015. A recommended calibration and validation strategy for hydrologic and water quality models. Trans. ASABE 58(6): 1705-1719.

Douglas-Mankin, K.R., Srinivasan, R., Arnold, J.G., 2010a. Soil and Water Assessment Tool (SWAT) model: Current developments and applications. Trans. ASABE 53(5): 1423-1431.

Douglas-Mankin, K.R., Maski, D., Janssen, K.A., Tuppad, P., Pierzynski, G.M., 2010b. Modeling nutrient runoff yields from combined in-field crop practices using SWAT. Trans. ASABE 53(5): $1557-1568$. 
Douglas-Mankin, K.R., Daggupati, P., Sheshukov, A. Y., Barnes, P. L., 2013. Paying for sediment: Field-scale conservation practice targeting, funding, and assessment using SWAT. J. Soil Water Cons. 68(1): 41-51.

Engel, B.A., Chaubey, I., Thomas, M.A., Saraswat, D., Murphy, P., Bhaduri, B., 2010. Biofuels and water quality: Challenges and opportunities for simulation modeling. Future Science Group: Biofuels 1(3): 463-477

Gali, R.K., Douglas-Mankin, K.R., Li, X., Xu, T., 2012. Assessing NEXRAD P3 data effects on stream-flow simulation using SWAT model in an agricultural watershed. J. Hydrol. Eng. 17(11): $1245-1254$.

Gassman, P.W., Reyes, M.R., Green, C.H., Arnold, J.G., 2007. The Soil and Water Assessment Tool: Historical development, applications, and future research directions. Trans. ASABE 50(4): 12111250.

Gowda, P.H., Mulla, D.J., Desmond, E.D., Ward, A.D., Moriasi, D.N., 2012. ADAPT: Model use, calibration, and validation. Trans. ASABE 55(4): 1345-1352.

Hargreaves G.H., Samani Z.A., 1985. Reference crop evapotranspiration from temperature. Appl. Eng. Agric. 1(2): 96-99.

Hlophe, H.B., 2014. Sweet sorghum (Sorghum bicolor (L.) Moench) response to supplemental irrigation in different growth stages. M.S. Thesis., University of Pretoria, South Africa.

Hu, X., McIsaac, G.F., David, M.B., Louwers, C.A.L., 2007. Modeling riverine nitrate export from an east-central Illinois watershed using SWAT. J. Environ. Qual. 36: 996-1005.

Knisel, W., Douglas-Mankin, K.R., 2012. CREAMS/GLEAMS: Model use, calibration, and validation. Trans. ASABE. 55(4): 1291-1302.

Kansas State University Agricultural Experiment Station and Cooperative Extension Service (KSUAES-CES), 1999-2008a. Kansas Performance Tests with Grain Sorghum Hybrids. Reports of Progress 844, 865, 883, 900, 915, 933, 950, 969, 986, 1004.

Kansas State University Agricultural Experiment Station and Cooperative Extension Service (KSUAES-CES), 1999-2008b. Kansas Performance Tests with Corn Hybrids. Reports of Progress 843, 860, 882, 899, 914, 932, 949, 968, 983, 1000. 
Lee, M.C., Douglas-Mankin, K.R., 2011. An environmental trading ratio for water quality trading: Definition and analysis. Trans. ASABE 54(5): 1599-1614.

Luo, Y., He, C., Sophocleous, M., Yin, Z., Hongrui, R., Ouyang, Z., 2008. Assessment of crop growth and soil water modules in SWAT 2000 using extensive field experiment data in an irrigation district of the Yellow River Basin. J. Hydrol. 352: 139-156.

Mankin, K.R., Ward, A.D., Boone, K.M., 1996. Quantifying changes in soil physical properties from soil and crop management: A survey of experts. Trans. ASAE 39(6): 2065-2074.

Maski, D., Mankin, K.R., Janssen, K.A., Tuppad, P., Pierzynski, G.M., 2008. Modeling runoff and sediment yields from combined in-field crop practices using SWAT. J. Soil Water Cons. 63(4): 193-203.

Moriasi, D.N., Arnold, J.G., Van Liew, M.W., Bingner, R.L., Harmel, R.D., Veith, T.L., 2007. Model evaluation guidelines for systematic quantification of accuracy in watershed simulations. Trans. ASABE 50(3): 885-900.

Moriasi, D.N., M.W. Gitau, N. Pai, P. Daggupati, 2015. Hydrologic and water quality models: Performance measures and evaluation criteria. Trans. ASABE 58(6): 1763-1785.

Mueller, R., Seffrin, R., 2006. New methods and satellites: A program update on the NASS cropland data layer acreage program. Intl. Archives Photogrammetry, Remote Sensing, and Spatial Information Sci., Vol. XXXVI-8/W48. International Society for Photogrammetry and Remote Sensing (ISPRS).

Nair, S.S., King, K.W., Witter, J.D., Sohngen, B.L., Fausey, N.R., 2011. Importance of crop yield in calibrating watershed water quality simulation tools. J. Amer. Water Resour. Assoc. 47(6): 12851297.

Nash, J.E., Sutcliffe, J.V., 1970. River flow forecasting through conceptual models: Part I. A discussion of principles. J. Hydrol. 10(3): 282-290.

National Climate Data Center (NCDC), 2011. Locate Weather Observation Station Record. Washington, D.C., NCDC. Available at: http://www.ncdc.noaa.gov/oa/climate/stationlocator.html. Accessed June 2011 
Neitsch, S.L., Arnold, J.G., Kiniry, J.R., Srinivasan, R., Williams, J.R., 2004. Soil and Water Assessment Tool Input / Output File Documentation version 2005. Temple, Texas: Grassland, Soil and Water Research Laboratory, USDA-ARS and Blackland Research and Extension Center, Texas A\&M University.

Neitsch, S.L., Arnold, J.G., Kiniry, J.R., Williams, J.R., 2005. Soil and Water Assessment Tool Theoretical Documentation, Version 2005. Temple, Texas, Grassland, Soil and Water Research Laboratory, USDA-ARS and Blackland Research and Extension Center, Texas A\&M University.

Nejadhashemi, A.P., Woznicki, S.A., Douglas-Mankin, K.R., 2011. Comparison of four models (STEPL, PLOAD, L-THIA, SWAT) in simulating sediment, nitrogen, and phosphorus loads and pollutant source areas. Trans. ASABE 54(3): 875-890.

Ng, T.L., Eheart, J.W., Cai, X., Miguez, F., 2010. Modeling miscanthus in the Soil and Water Assessment Tool (SWAT) to simulate its water quality effects as a bioenergy crop. Environ. Sci. Technol. 44(18): 7138-7144.Oklahoma Cooperative Extension Service (OCES), 2006. OCES: Oklahoma Corn Performance Trials, 2006. Production Technology Crops 18(12).

Oklahoma Cooperative Extension Service (OCES), 2007. OCES: Oklahoma Corn Performance Trials, 2007. Production Technology Crops 19(9).

Oklahoma Cooperative Extension Service (OCES), 2008. OCES: Oklahoma Corn Performance Trials, 2008. Production Technology Crops 20(5).

Oklahoma Cooperative Extension Service (OCES), 2009. OCES: Oklahoma Corn Performance Trials, 2009. Production Technology Crops 22(3).

Oklahoma Cooperative Extension Service (OCES), 2010. OCES: Oklahoma Corn Performance Trials, 2010. Production Technology Crops 22(7).

Parajuli, P.B., Mankin, K.R., Barnes, P L., 2009a. Source specific fecal bacteria modeling using Soil and Water Assessment Tool model. Bioresource Tech. 100(2): 953-963.

Parajuli, P.B., Nelson, N.O., Frees, L.D., Mankin, K.R., 2009b. Comparison of AnnAGNPS and SWAT model simulation results in USDA-CEAP agricultural watersheds in south-central Kansas. Hydrol. Proc. 23(5): 748-763. 
Parajuli, P.B., Douglas-Mankin, K.R., Barnes, P.L., Green, C.H., 2009c. Fecal bacteria source characterization and sensitivity analysis of SWAT 2005. Trans. ASABE 52(6): 1847-1858.

Perkins, S.A., Douglas-Mankin, K.R., Nelson, R., Staggenborg, S., 2011. Modeling the economic feasibility of sweet sorghum in western Kansas and the panhandles of Texas and Oklahoma. ASABE Paper No. 11-11718. St. Joseph, Mich., ASABE.

Perkins, S.A., 2012. Crop Model Review and Sweet Sorghum Crop Model Parameter Development. M.S. thesis, Dept. of Biological and Agricultural Engineering., College of Engineering., Kansas State University., Manhattan, KS.

Propheter, J.L., 2009. Direct Comparison of Biomass Yields of Annual and Perennial Biofuel Crops. PhD diss. Manhattan, Kansas: Kansas State University.

Roncucci, N., Triana, N., Tozzini, C., Bonari, E., Ragaglini, G., 2014. Double row spacing and drip irrigation as technical options in energy sorghum management. Italian J. Agronomy 9(1): 25-32.

Sakellariou-Makrantonaki, M., Papalexis, D., Nakos, N., Kalavrouziotis, I.K., 2007. Effect of modern irrigation methods on growth and energy production of sweet sorghum (var. Keller) on a dry year in Central Greece. Agricultural Water Management 90: 181-189.

Sheshukov, A.Y., Siebenmorgen, C.B., Douglas-Mankin, K.R., 2011a. Seasonal and annual impacts of climate change on watershed response using ensemble of global circulation models. Trans. ASABE 54(6): 2209-2218.

Sheshukov, A.Y., Daggupati, P., Douglas-Mankin, K.R., Lee, M., 2011b. High spatial resolution soil data for watershed modeling: 1. Development of a SSURGO-ArcSWAT utility. J. Natural and Environ. Sci. 2(2): 15-24.

Sheshukov, A.Y., Daggupati, P., Douglas-Mankin, K.R., 2011c. High spatial resolution soil data for watershed modeling: 2. Assessing impacts on watershed hydrologic response. J. Natural and Environ. Sci. 2(2): 32-41.

Sheshukov, A.Y., Douglas-Mankin, K.R., Sinnathamby, S., Daggupati, P., 2013. Pasture BMP effectiveness using a HRU-based subarea approach in SWAT. J. Environ. Mgmt. 166: 276-284. doi: 10.1016/j.jenvman.2015.10.023. 
Sinclair, T.R., Seligman, N.G., 1996. Crop modeling: From infancy to maturity. Agron. J. 88: 698703.

Srinivasan, R., Zhang, X., Arnold, J., 2010. SWAT ungauged: Hydrological budget and crop yield predictions in the upper Mississippi River basin. Trans. ASABE 53(5): 1533-1546.

Trybula, E.M., Cibin, R., Burks, J.L., Chaubey, I., Brouder, S.M., Volenec, J.J., 2015. Perennial rhizomatous grasses as bioenergy feedstock in SWAT: Parameter development and model improvement. GCB Bioenergy 7: 1185-1202. doi: 10.1111/gcbb.12210.

Tuppad, P., Douglas-Mankin, K.R., Koelliker, J.K., Hutchinson, J.M.S., 2010a. SWAT discharge response to spatial rainfall variability in a Kansas watershed. Trans. ASABE 53(1): 65-74.

Tuppad, P., Douglas-Mankin, K.R., Koelliker, J.K., Hutchinson, J.M.S., Knapp, M.C., 2010b. NEXRAD Stage III precipitation local bias adjustment for streamflow prediction. Trans. ASABE 53(5): 1511-1520.

Tuppad, P., Douglas-Mankin, K.R., Lee, T., Srinivasan, R., Arnold, J.G., 2011. Soil and Water Assessment Tool (SWAT) hydrologic/water quality model: Extended capability and wider adoption. Trans. ASABE 54(5): 1677-1684.

U.S. Geological Survey (USGS), 2010. United States Geological Survey National Map Seamless Server. Available at: http://landcover.usgs.gov/natllandcover.php. Accessed 30 August 2012.

U.S. Geological Survey (USGS), 1992. The USGS Land Cover Institute (LCI) National Land Cover Dataset 1992. Available at: http://landcover.usgs.gov/natllandcover.php. Accessed 30 August 2012.

U.S. Department of Agriculture (USDA), 2011. Natural Resources Conservation Service: Soil Survey Geographic (SSURGO) Database. Available at: http://soils.usda.gov/survey/geography/ssurgo/. Accessed 30 August 2012.

Williams, J.R., Jones, C.A., Dyke, P.T., 1984. A modeling approach to determining the relationship between erosion and soil productivity. Trans. ASAE 27(1): 129-144.

Williams, J.R., 1995. The EPIC model. In: Computer Models of Watershed Hydrology, 909-1000. Singh, V.P. (Ed.), Highlands Ranch, Colo., Water Resources Publications. 
Table 1. Site RK (Riley County, KS) plant (PLNT) and harvest (HVST) dates and nitrogren and phosphorus fertilizer (FERT) application amounts (kg/ha) for corn, grain sorghum, and sweet sorghum.

\begin{tabular}{|c|c|c|c|c|c|c|c|c|}
\hline \multicolumn{3}{|c|}{ Corn } & \multicolumn{3}{|c|}{ Grain Sorghum } & \multicolumn{3}{|c|}{ Sweet Sorghum } \\
\hline PLNT & HVST & FERT & PLNT & HVST & FERT & PLNT & HVST & FERT \\
\hline $5 / 3 / 99$ & 9/17/99 & $168 \mathrm{~N}-00 \mathrm{P}$ & $5 / 26 / 99$ & $10 / 6 / 99$ & $168 \mathrm{~N}-00 \mathrm{P}$ & $5 / 21 / 07$ & $10 / 25 / 07$ & $168 \mathrm{~N}-67 \mathrm{P}$ \\
\hline $4 / 21 / 00$ & $9 / 6 / 00$ & $146 \mathrm{~N}-00 \mathrm{P}$ & $5 / 10 / 00$ & $9 / 15 / 00$ & $146 \mathrm{~N}-34 \mathrm{P}$ & $5 / 21 / 08$ & $10 / 3 / 08$ & $179 \mathrm{~N}-0 \mathrm{P}$ \\
\hline $4 / 17 / 01$ & $9 / 11 / 01$ & $146 \mathrm{~N}-00 \mathrm{P}$ & $5 / 14 / 01$ & $9 / 28 / 01$ & $146 \mathrm{~N}-34 \mathrm{P}$ & $5 / 29 / 09$ & $10 / 5 / 09$ & $179 \mathrm{~N}-0 \mathrm{P}$ \\
\hline $4 / 12 / 02$ & $9 / 9 / 02$ & $134 \mathrm{~N}-00 \mathrm{P}$ & $5 / 21 / 02$ & $9 / 30 / 02$ & $151 \mathrm{~N}-56 \mathrm{P}$ & $5 / 24 / 10$ & $10 / 1 / 10$ & $179 \mathrm{~N}-0 \mathrm{P}$ \\
\hline $4 / 14 / 03$ & $9 / 8 / 03$ & $134 \mathrm{~N}-00 \mathrm{P}$ & $5 / 13 / 03$ & $9 / 24 / 03$ & $151 N-67 P$ & & & \\
\hline $4 / 14 / 04$ & $9 / 16 / 04$ & $146 \mathrm{~N}-00 \mathrm{P}$ & $5 / 24 / 04$ & $10 / 16 / 04$ & $146 \mathrm{~N}-34 \mathrm{P}$ & & & \\
\hline $4 / 16 / 05$ & $9 / 19 / 05$ & $146 \mathrm{~N}-30 \mathrm{P}$ & $5 / 24 / 05$ & $9 / 27 / 05$ & $146 \mathrm{~N}-34 \mathrm{P}$ & & & \\
\hline 4/13/06 & $9 / 15 / 06$ & $146 \mathrm{~N}-30 \mathrm{P}$ & $5 / 18 / 06$ & $9 / 28 / 06$ & $146 \mathrm{~N}-34 \mathrm{P}$ & & & \\
\hline $4 / 23 / 07$ & $9 / 17 / 07$ & $134 \mathrm{~N}-00 \mathrm{P}$ & $5 / 11 / 07$ & $9 / 29 / 07$ & $146 \mathrm{~N}-34 \mathrm{P}$ & & & \\
\hline $4 / 23 / 08$ & $10 / 1 / 08$ & $101 \mathrm{~N}-00 \mathrm{P}$ & $5 / 16 / 08$ & $9 / 25 / 08$ & $146 \mathrm{~N}-34 \mathrm{P}$ & & & \\
\hline
\end{tabular}

Table 2. Site TO (Texas County, OK) plant (PLNT) and harvest (HVST) dates, and nitrogen and phosphorus fertilizer (FERT) application amounts (kg/ha) for corn and grain sorghum.

\begin{tabular}{ccccccc}
\hline & Corn & & & \multicolumn{3}{c}{ Grain Sorghum } \\
\cline { 1 - 3 } \cline { 7 - 7 } PLNT & HVST & \multirow{2}{*}{ FERT } & & PLNT & HVST & FERT \\
\hline $4 / 12 / 06$ & $9 / 20 / 06$ & $258 \mathrm{~N}-56 \mathrm{P}$ & $6 / 7 / 06$ & $11 / 17 / 06$ & $56 \mathrm{~N}-6 \mathrm{P}$ \\
$4 / 24 / 07$ & $9 / 7 / 07$ & $258 \mathrm{~N}-56 \mathrm{P}$ & $5 / 31 / 07$ & $9 / 20 / 07$ & $56 \mathrm{~N}-6 \mathrm{P}$ \\
$4 / 15 / 08$ & $10 / 1 / 07$ & $258 \mathrm{~N}-56 \mathrm{P}$ & $6 / 24 / 08$ & $11 / 6 / 08$ & $56 \mathrm{~N}-6 \mathrm{P}$ \\
$4 / 22 / 09$ & $9 / 24 / 09$ & $258 \mathrm{~N}-56 \mathrm{P}$ & $6 / 23 / 09$ & $11 / 3 / 09$ & $56 \mathrm{~N}-6 \mathrm{P}$ \\
$4 / 14 / 10$ & $9 / 21 / 10$ & $258 \mathrm{~N}-56 \mathrm{P}$ & $6 / 2 / 10$ & $10 / 29 / 10$ & $56 \mathrm{~N}-6 \mathrm{P}$ \\
\hline
\end{tabular}


Table 3. Sweet sorghum calibrated SWAT crop parameter values.

\begin{tabular}{|c|c|c|c|c|}
\hline Name & Parameter Description & & $\begin{array}{c}\text { Grain } \\
\text { Sorghum }\end{array}$ & $\begin{array}{c}\text { Sweet } \\
\text { Sorghum }\end{array}$ \\
\hline \multicolumn{5}{|c|}{ Values calibrated for Sweet Sorghum } \\
\hline BIO_E & Radiation use efficiency $\left(10^{-1} \mathrm{~g} / \mathrm{MJ}\right)$ & (Range: $39-50)$ & 33.5 & 50 \\
\hline BLAI & Max. leaf area index & (Range: $5-6)$ & $3(5)^{1}$ & 6 \\
\hline HVSTI & Harvest index & (Range: $0.90-1.00)$ & $0.45(0.46)^{1}$ & $1.0^{2}$ \\
\hline WSYF & Lower limit of harvest index & (Range: $0.90-1.00)$ & $0.25(0.35)^{1}$ & $1.0^{2}$ \\
\hline \multicolumn{5}{|c|}{ Values modified from Grain Sorghum (Perkins et al., 2011; Propheter, 2009; BAE, 2006) } \\
\hline T_BASE & Base temperature needed for plant gro & & 11 & 10 \\
\hline BN1 & Fraction of $\mathrm{N}$ in plant at emergence & & 0.044 & 0.018 \\
\hline $\mathrm{BN} 2$ & Fraction of $\mathrm{N}$ in plant at $1 / 2$ maturity & & 0.0164 & 0.0093 \\
\hline BN3 & Fraction of $\mathrm{N}$ in plant at maturity & & 0.0128 & 0.0051 \\
\hline BP1 & Fraction of $\mathrm{P}$ in plant at emergence & & 0.006 & 0.002 \\
\hline BP2 & Fraction of $\mathrm{P}$ in plant at $1 / 2$ maturity & & 0.0022 & 0.001 \\
\hline BP3 & Fraction of $\mathrm{P}$ in plant at maturity & & 0.0018 & 0.0003 \\
\hline \multicolumn{5}{|c|}{ Values adopted from Grain Sorghum without adjustment } \\
\hline RDMX & Max. root depth & & 2 & 2 \\
\hline FRGRW1 & $\begin{array}{l}\text { Fraction of growing season at } 1^{\text {st }} \text { poin } \\
\text { curve }\end{array}$ & on optimal leaf area development & 0.15 & 0.15 \\
\hline LAIMX1 & Fraction of BLAI at $1^{\text {st }}$ point on optim & leaf area development curve & 0.05 & 0.05 \\
\hline FRGRW2 & $\begin{array}{l}\text { Fraction of growing season at } 2^{\text {nd }} \text { poin } \\
\text { curve }\end{array}$ & on optimal leaf area development & 0.5 & 0.5 \\
\hline LAIMX2 & Fraction of BLAI at $2^{\text {nd }}$ point on optin & 1 leaf area development curve & 0.95 & 0.95 \\
\hline WAVP & Decline in RUE per unit increase in va & or pressure deficit (VPD) & 8.5 & 8.5 \\
\hline DLAI & Fraction of growing season when leaf & rea starts declining & 0.64 & 0.64 \\
\hline T_OPT & Optimal temperature for plant growth & & 30 & 30 \\
\hline BIOEHI & Radiation use efficiency at elevated C & & 36 & 36 \\
\hline USLE_C & Min. value of USLE_C factor applica & le to land cover & 0.2 & 0.2 \\
\hline GSI & Max. stomatal conductance in drough & onditions & 0.005 & 0.005 \\
\hline VPDFR & VPD at FRGMAX & & 4 & 4 \\
\hline FRGMAX & Fraction of max. stomatal conductanc & achievable at high VPD & 0.75 & 0.75 \\
\hline CNYLD & Fraction of $\mathrm{N}$ in harvested biomass & & 0.0199 & 0.0199 \\
\hline CPYLD & Fraction of $\mathrm{P}$ in harvested biomass & & 0.0032 & 0.0032 \\
\hline $\mathrm{CO} 2 \mathrm{HI}$ & Elevated $\mathrm{CO}_{2}$ atmospheric concentrati & & 660 & 660 \\
\hline CHTMX & Maximum canopy height & & 3.5 & 3.5 \\
\hline RSDCO_PL & Plant residue decomposition coefficie & & 0.05 & 0.05 \\
\hline BM_DIEOFF & Biomass die-off fraction & & 0.1 & 0.1 \\
\hline
\end{tabular}

${ }^{1}$ Calibrated values (from this study, below) in parentheses.

${ }^{2}$ Harvest index of 1.0 (i.e., harvested $100 \%$ of above-ground biomass) was artifact of plot-scale research study conditions. 
Table4. Corn and grain sorghum SWAT crop growth parameter calibrated values, default values, and tested ranges.

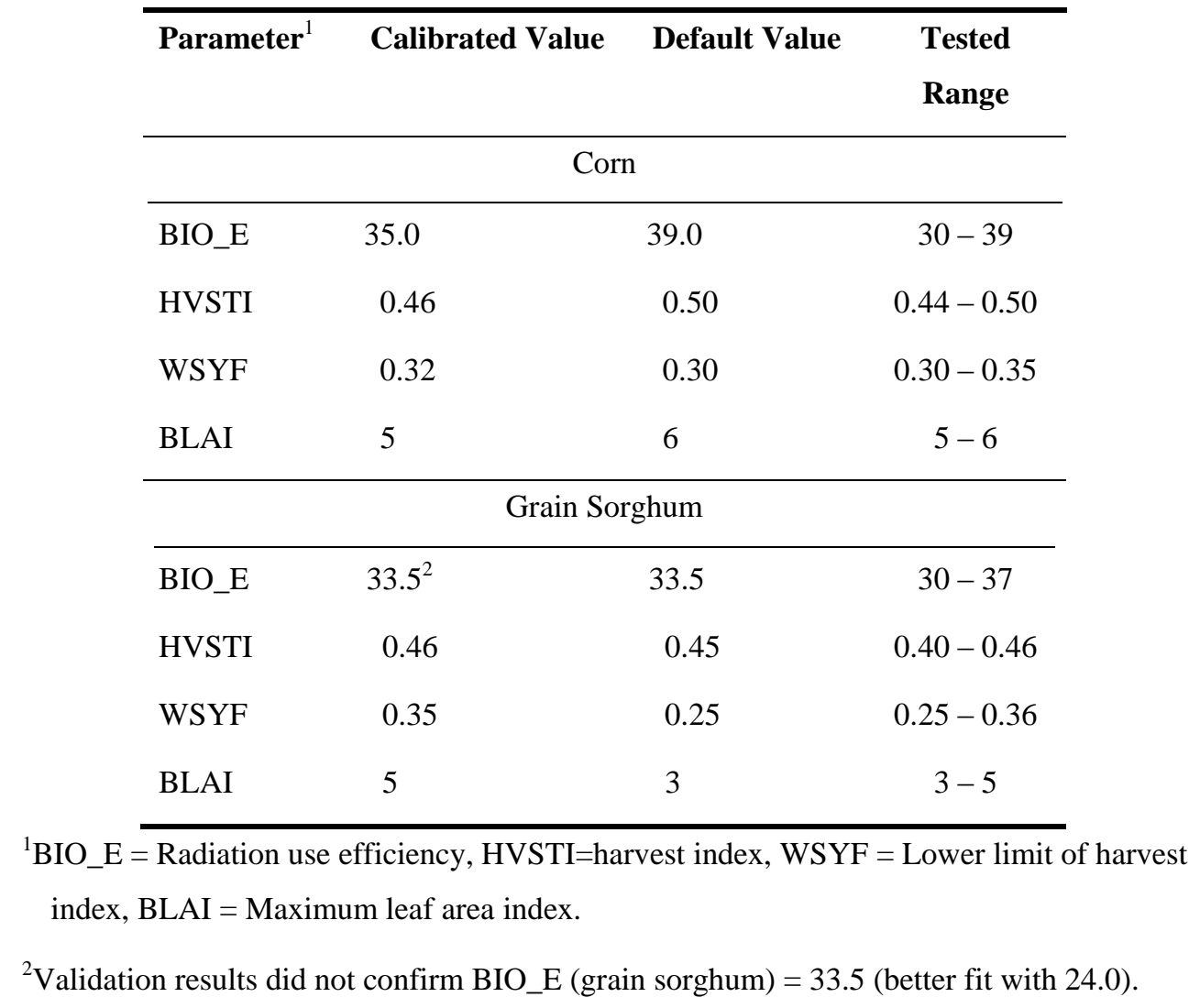

Table 5. Corn and grain sorghum SWAT soil/hydrological parameter calibrated values, default values, and tested ranges.

\begin{tabular}{lcccl}
\hline Parameter & $\begin{array}{c}\text { Calibrated } \\
\text { Value }\end{array}$ & $\begin{array}{c}\text { Default } \\
\text { Value }\end{array}$ & Tested Range & \multicolumn{1}{c}{ Reasons } \\
\hline EPCO & 0.9 & 1.0 & $0.9-1.0$ & $\begin{array}{l}\text { Decreased to allow plant to meet water needs from lower soil } \\
\text { layers to reduce water stress. }\end{array}$ \\
ESCO & 0.6 & 0.95 & $0.6-0.95$ & $\begin{array}{l}\text { Decreased to allow moisture from lower soil levels to be drawn } \\
\text { into upper layers to decrease water stress. }\end{array}$ \\
NPERCO & 0.5 & 0.2 & $0.05-0.7$ & $\begin{array}{l}\text { Modification decreased nitrogen that remained available in the } \\
\text { soil for plant uptake. }\end{array}$ \\
BIOMIX & 0.4 & 0.2 & $0.2-0.4$ & $\begin{array}{l}\text { Increased soil mixing allowing for better nutrient uptake. } \\
\text { Increased to decrease plant water stress, increasing yield. }\end{array}$ \\
SOL_AWC 1617170-1 & 0.24 & 0.23 & $0.23-0.25$ & \begin{tabular}{l} 
Decreased to increase plant water stress, thereby reducing yield. \\
\hline
\end{tabular}
\end{tabular}




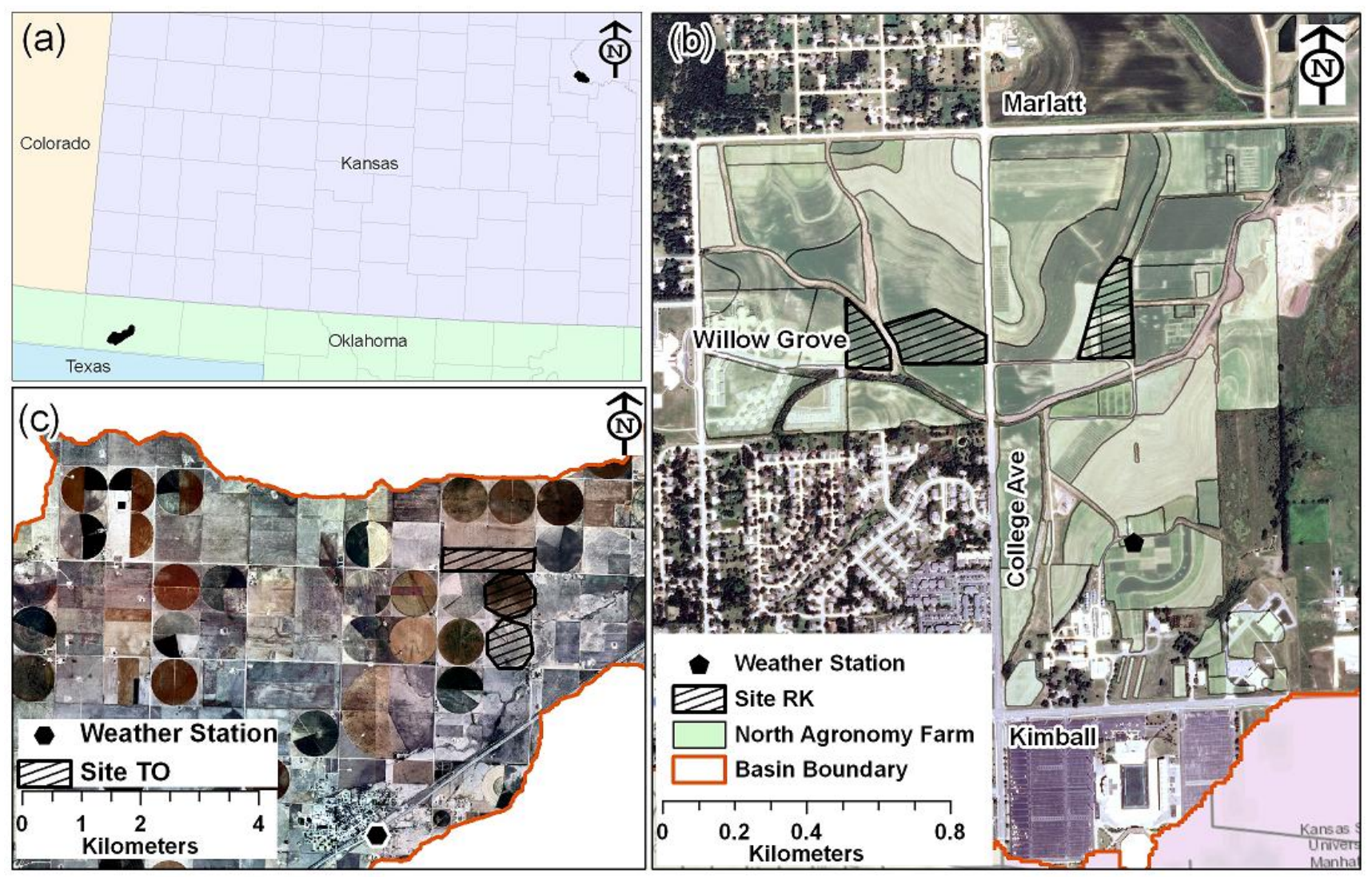

Figure 1. (a) Locations of two study areas: Cedar Creek Watershed, Riley County, KS (Site RK) and Lower Golf Creek Watershed, Texas County, OK (Site TO). Areal image maps with studied fields (b) Sites RK within North Agronomy Fields and (c) Site TO. 


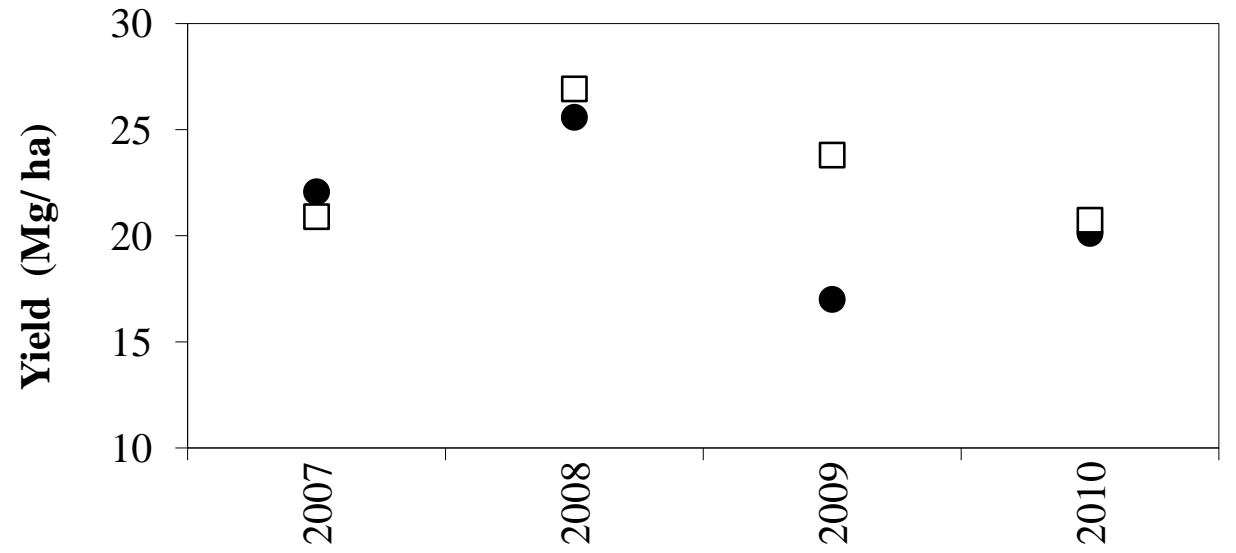

Figure 2. Sweet sorghum biomass yield calibration. SWAT modeled $(\bullet)$ and observed $\left({ }^{(}\right)$for Site RK (Riley County, KS) using new crop parameters. 


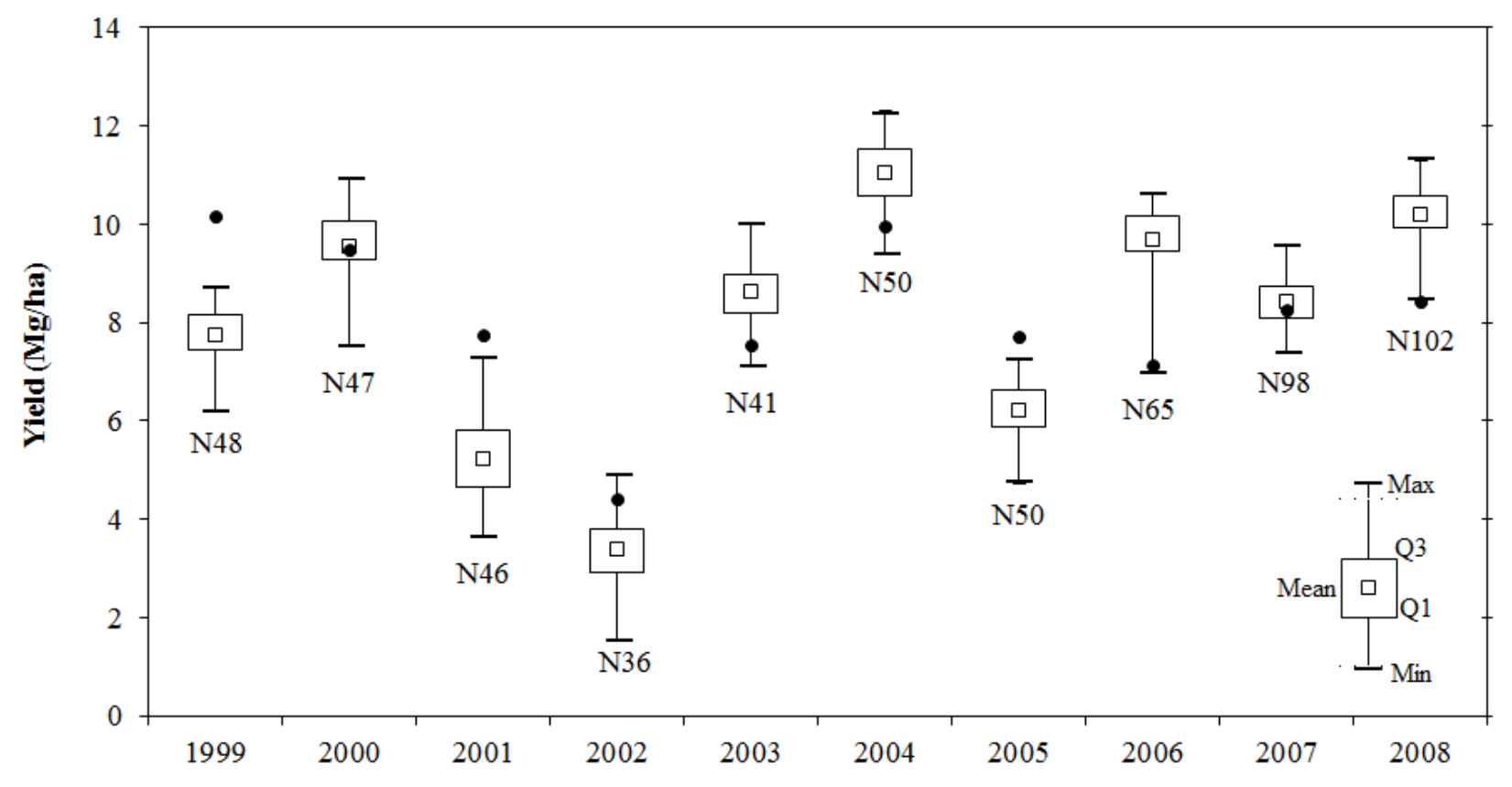

Figure 3. Corn yield calibration. SWAT modeled $(\bullet)$ and observed ( $\square$, box and whisker) for Site RK (Riley County, KS). Number of cultivar plots (N) used in this study ranged from 36 to 102 among years. Natural extreme events occurred in 1999 (heavy rains), 2001 (hailstorm), and 2006 (low rainfall). 


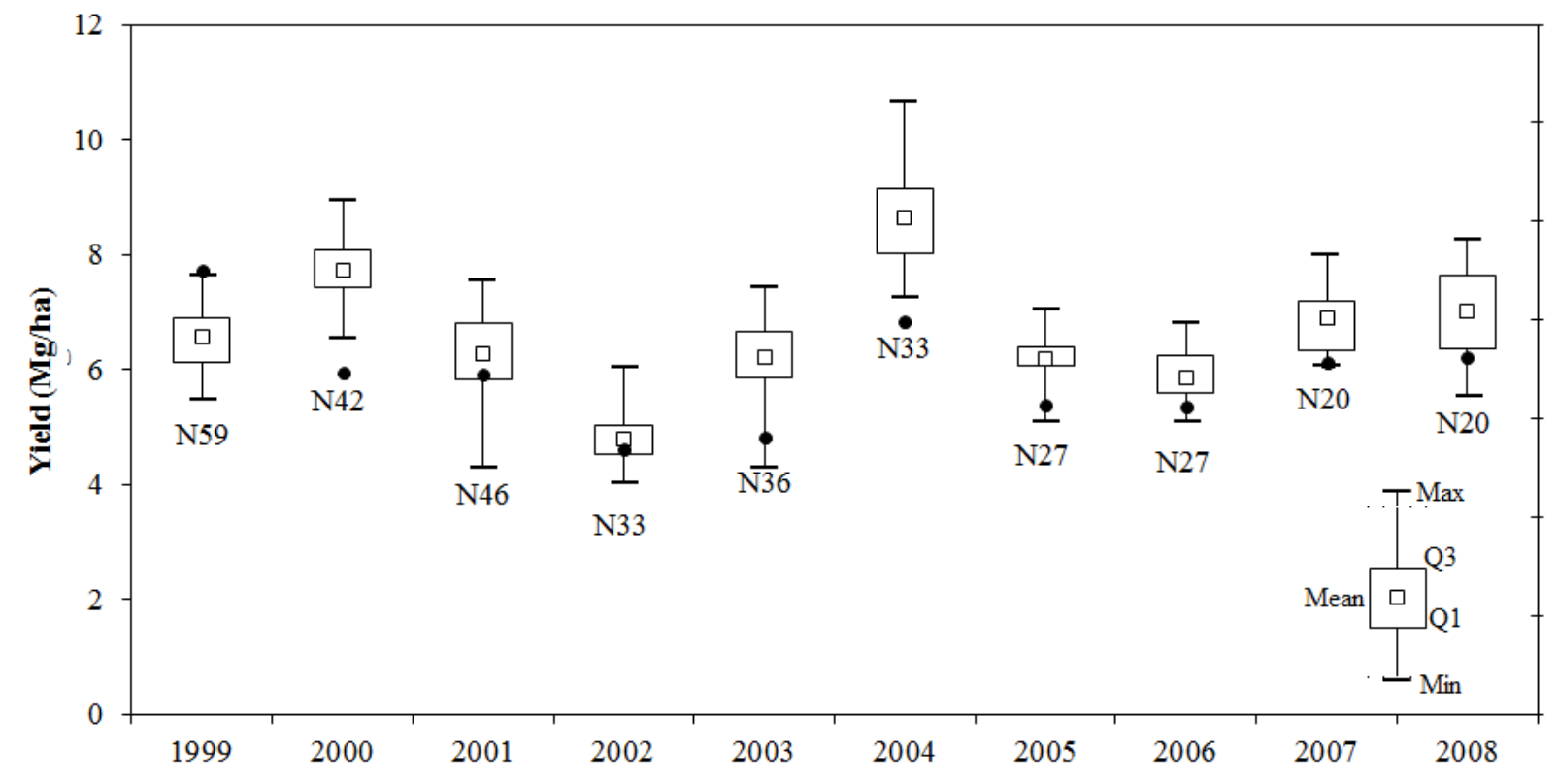

Figure 4. Grain sorghum yield calibration. SWAT modeled (•) and observed ( ${ }^{\circ}$, box and whisker) from 1999 to 2008 for Site RK (Riley County, KS). Number of cultivar plots (N) used in this study ranged from 20 to 59 among years. Extreme rainfall in 1999 may have removed fertilizer, contributing to the over-prediction. 


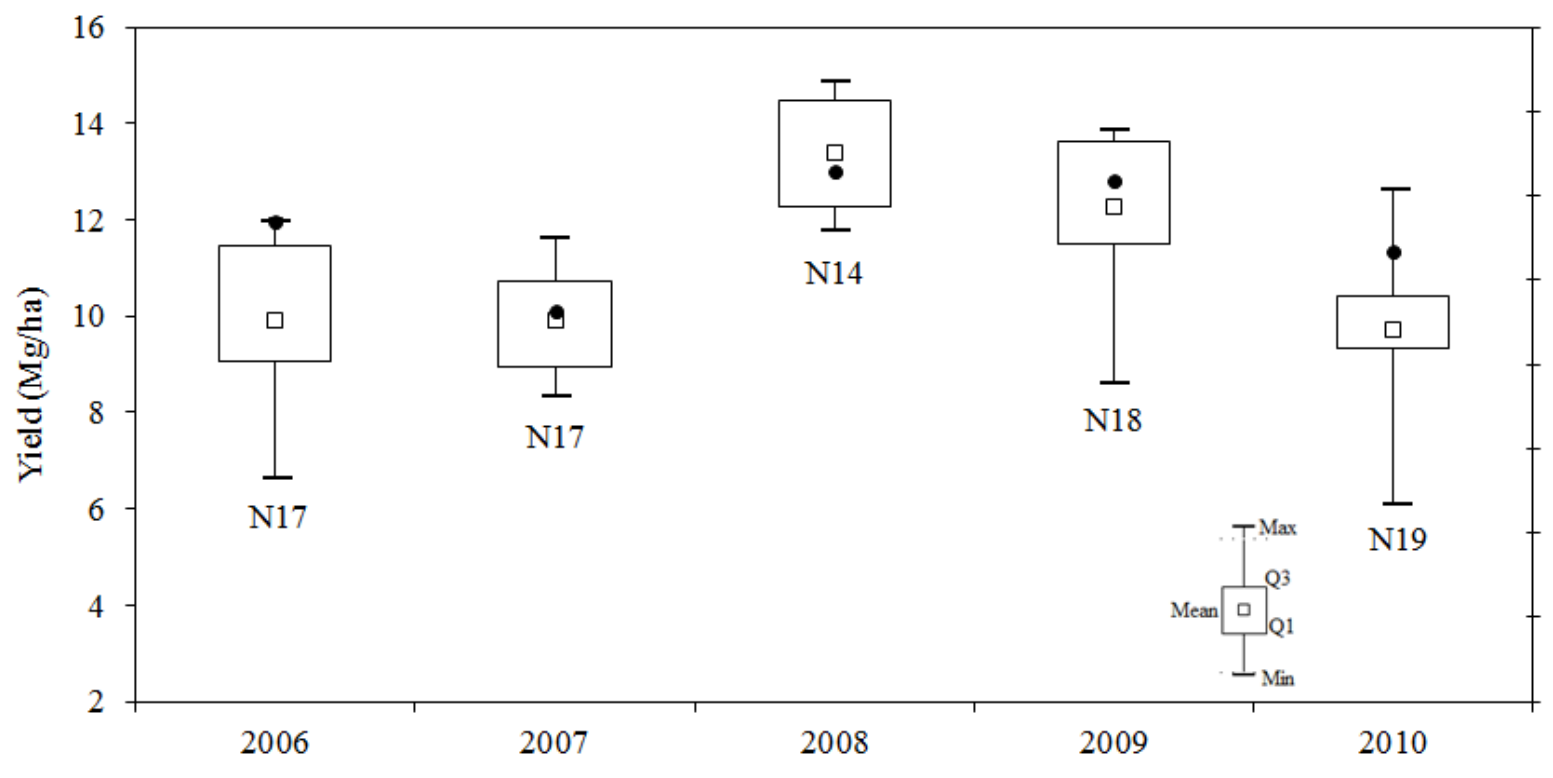

Figure 5. Corn yield validation. SWAT modeled (•) and observed ( $($, box and whisker) from 2006 to 2010 for Site TO (Texas County, OK). Number of cultivar plots $(\mathrm{N})$ used in this study ranged from 14 to 19 among years. 


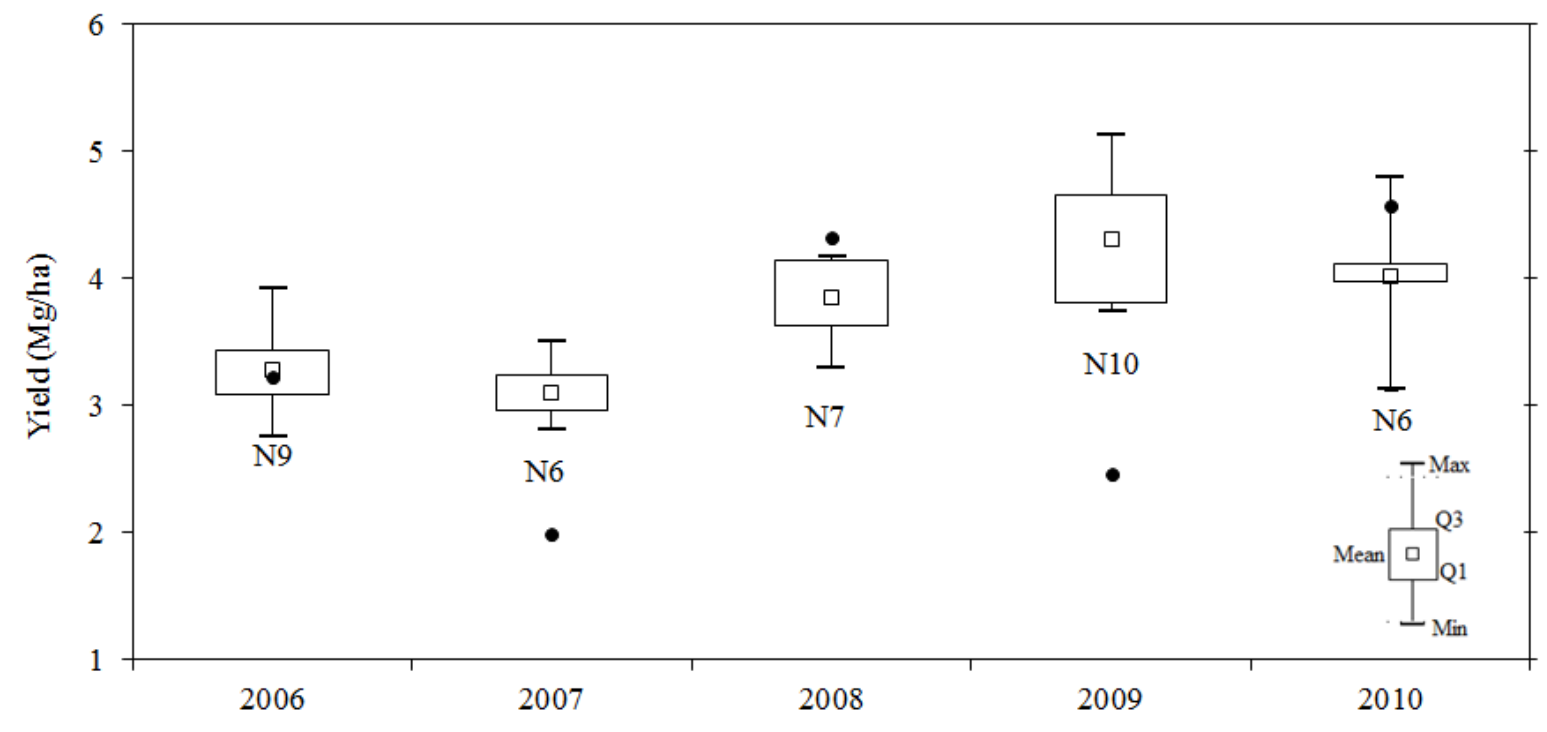

Figure 6. Grain sorghum yield validation. SWAT modeled $(\bullet)$ and observed ( $\square$, box and whisker) from 2006 to 2010 for Site TO (Texas County, OK). Number of cultivar plots (N) used in this study ranged from 6 to 10 among years. SWAT appeared to over-stress sorghum crop yields in response to droughts in 2007 and 2009. 